Article

\title{
Competencies and Practices in Academic Engineering Leadership Development: Lessons from a National Survey
}

\author{
Diane Magrane $^{1, * \mathbb{C}}$, Page S. Morahan ${ }^{1}$, Susan Ambrose ${ }^{2}$ and Sharon A. Dannels ${ }^{3}$ \\ 1 Institute for Women's Health and Leadership, Drexel University College of Medicine, \\ Philadelphia, PA 19129 ,USA; pm36@drexel.edu \\ 2 Office of the Provost, Northeastern University, Boston, MA 02115, USA; s.ambrose@northeastern.edu \\ 3 Department of Educational Research, George Washington University, Washington, WA 20052, USA; \\ sdannels@gwu.edu \\ * Correspondence: dmm347@drexel.edu; Tel.: +1-215-991-8240
}

Received: 4 September 2018; Accepted: 18 September 2018; Published: 21 September 2018

\begin{abstract}
Traditionally, higher education has relied on recruiting executive leaders based largely on scholarly credibility, expecting leadership competency to develop with "on the job" experience. This approach is risky to organizational success. Building upon research about how institutional leaders identify, select, develop, and support those in succession, this study aims (1) to explore how senior academic leaders in engineering perceive their leadership roles, specifically the importance they attribute to various leadership skills and their self-confidence in exercising those skills, and (2) to discern the prevalence of mentoring and sponsorship practices those leaders use as part of their leadership portfolio. Results of a national survey, distributed in collaboration with the American Society for Engineering Education (ASEE) to leaders in academic engineering in North America, confirm the importance of select leadership skills, including practices related to the mentoring and sponsorship of emerging leaders. However, the reported prevalence of those practices was relatively low in this sample. The authors recommend holding leaders accountable for developing future leaders and present an instrument for self- and organizational assessment of such practices for use in implementing more intentional approaches to leadership development in higher education.
\end{abstract}

Keywords: leadership competencies in higher education; mentoring and sponsorship practices; academic engineering; inclusive leadership development; self-assessment

\section{Introduction}

Global corporations are tackling organizational challenges through systems that identify and develop internal potential leaders (Korn Ferry Institute 2015); however, academia has been slower to adopt what has been called "one of the best attributes of business culture: Its tradition of developing leadership through succession planning" (Blumenstyk 2005). In higher education, the recruitment of executive leaders continues to rely, as it has traditionally, on scholarly credibility, viewing management and leadership opportunities largely as voluntary service roles. Deans and department chairs are selected primarily for expertise in their fields of scholarship, with the expectation that their scholarly success will transfer to effectiveness as institutional leaders. Moreover, academic leadership positions have historically been time-limited appointments, after which the leader returns to teaching and research. This tradition can lead to a conservative approach to organizational change, with leaders trying to avoid creating relational and political conflict (Rowley and Sherman 2003; Gmelch 2004). 
For almost two decades, scholars of academic leadership development have been calling for new talent management processes that identify, inspire, and prepare diverse faculty for administrative leadership roles (Gmelch 2000; Clunies 2004; Betts et al. 2009; González 2010; Gigliotti and Ruben 2017). A recent study of department chair preparation revealed the continuation of "just in time" learning of administrative leadership skills, through consultation with colleagues and experience gained through handling challenges (Gmelch et al. 2017). On-the-job training may have worked well in decades' past. Today, universities are increasingly called to take more strategic and inclusive approaches to business practices, institutional change, community engagement, and entrepreneurship (King and Sen 2013; Rizvi et al. 2013). In addition to requiring a new skill set for academic leaders, some of these expectations create tension with traditional academic values (Morahan et al. 2016). In response, some contemporary leaders recognize the distinct skill sets needed for leadership and are preparing themselves with formal leadership education and executive coaching (Kaufman 2006).

These trends in professional development in academic leadership are promising, but insufficient. The development of academic leadership for the current era would benefit from a better understanding of how current leaders view their leadership abilities, including practices they use to identify, select, develop, and support emerging leaders. A recent qualitative study of 32 science, engineering, and math (STEM) academic leaders described these roles in terms of "matching" talent to positions, counseling and advocating for protégés' advancement, and supporting organizational goals (Magrane et al. 2018). The present study was designed to build on those interviews through a national survey of engineering leaders conducted with the American Society for Engineering Education's (ASEE) Engineering Deans Council (EDC) (executive leaders consisting of deans, provosts, department chairs, and directors). The aims of this national survey study were (1) to learn more about how senior academic leaders in engineering perceive their leadership roles, specifically the importance they attribute to various leadership skills and their self-confidence in exercising those skills; and (2) to discern the prevalence of mentoring and sponsorship practices these leaders use as part of their leadership portfolio.

\section{Materials and Methods}

The national survey was designed and delivered as the Academic Leadership Survey in collaboration with the ASEE, which has a membership of more than 12,000 individuals and includes representation of more than 400 colleges and universities. The survey was distributed to 355 members of the EDC, composed of the executive leaders (deans, provosts, department chairs, and directors) of the ASEE. The survey is available from the authors upon request.

\subsection{Survey Development}

The Academic Leadership Survey was designed with an introductory statement of consent that included a purpose and assurance that responses were confidential. This statement was followed by three sections for response. Section I asks respondents to rate their self-confidence in and their assessment of the importance of specific leadership competencies (skills and attitudes about leadership in higher education). Section II asks respondents about their behaviors related to mentoring and sponsorship for high-potential academic leaders. Section III asks respondents to describe the basic characteristics of their background and their organization.

For Section I (leadership competencies), 14 items were adapted from the previously validated 47-item Leadership Learning and Career Development (LLCD) survey (unpublished; available from authors), used to evaluate outcomes of national leadership development programs for senior academic women in STEM (Magrane and Morahan 2016). These items measure respondents' self-confidence and their perceptions of the importance of personal and professional leadership practices, strategic finance and resource management, organizational dynamics, and communities of leadership practice. Using a six-point rating scale (with a seventh option N/A for not applicable), the survey asks respondents to assess how important the skill or trait is to their current role and how self-confident they feel in 
performing the skill or related actions. The scale is anchored with Not important/not confident (1) and Very important/very confident (6).

Section II items (mentoring and sponsorship) were developed based on a review of the current literature and analysis of key informant interviews with leaders in STEM education (Magrane et al. 2018). Survey respondents were asked to consider up to three protégés and, for each protégé identified, rate a list of sponsorship and mentoring activities according to whether they employed the behavior: Always, Most of the time, Occasionally, Never, or N/A (not applicable). Items were coded according to whether they represented behaviors associated with mentoring or sponsorship.

All items were formatted in a Qualtrics ${ }^{\circledR}$ (Provo, UT, USA) survey and pilot tested by eight faculty and staff with expertise in higher education leadership and survey methodology. After minor revisions to reduce the number of items and clarify the wording of two items, the survey was shared with the leadership of the ASEE for further evaluation of face validity. No additional revisions were suggested.

\subsection{Data Collection Procedures}

The EDC (executive committee of the ASEE) reviewed and approved the project. The authors' institutional review board determined the project status as exempt (review 22 October 2014, ID\# 1205001285). Subsequently, the executive director of the ASEE sent an email invitation to ASEE-EDC members. The invitation included a link to the survey and assurance that responses would be anonymous. The survey was distributed, with two reminder emails, over the course of six weeks in late 2014.

\subsection{Data Analysis}

Descriptive information from Qualtrics ${ }^{\circledR}$ reports and survey responses were uploaded using SPSS software (IBM; Armonk, NY, USA) for data management and statistical analysis. For Section I, data were analyzed descriptively to explore patterns of responses for individual survey items. The median responses were calculated as well as frequencies and percentages for each item. Although the data were not reported as subscale scores, the reliability of internal consistency was determined using Cronbach $\alpha$ and was 0.78 for importance and 0.83 for self-confidence $(\mathrm{N}=82$; 14 items). These levels are consistent with those from the original LLCD survey from which the items were drawn and are generally accepted as more than sufficient evidence of reliability (Cohen and Swerdlik 2005). For the few surveys in which no response to an item was provided, the values were treated as missing data. To display the data, values from the six-point response scale were combined to enhance readability. Scores of 1 and 2 were combined as Not important or minimally important/self-confident, 3 and 4 were combined as Moderately important/self-confident, and 5 and 6 were combined as Very important/self-confident.

For Section II of the survey, respondents reported the frequency with which they engaged in eight mentoring and 12 sponsorship behaviors with up to three mentees. These data were analyzed using medians, frequencies, and percentages for each item. The demographic data reported in Section III were also analyzed descriptively (medians, frequencies, and percentages), and $\chi^{2}$ goodness-of-fit tests were done to compare the sample with the EDC population in terms of the distribution of gender and race. All assumptions of the $\chi^{2}$ test were met and 0.05 was used as the level of significance.

\section{Results}

\subsection{Characteristics of the Survey Population and Respondent Sample}

From a potential sample of 355 leaders from 350 institutions, 85 (24\%) completed the survey, and 76 of these respondents provided demographic and professional characteristics. Table 1 reports basic characteristics of respondents compared with ASEE-EDC members overall. 
Table 1. Characteristics of American Society for Engineering Education (ASEE) leaders and respondents to survey of engineering education leaders.

\begin{tabular}{|c|c|c|}
\hline & $\begin{array}{l}\text { ASEE-EDC Members * } \\
\qquad \mathbf{N}=355\end{array}$ & $\begin{array}{l}\text { Survey Respondents } \\
\qquad N=76\end{array}$ \\
\hline \multicolumn{3}{|l|}{ Role/position } \\
\hline Dean & $307(86 \%)$ & $52(68 \%)$ \\
\hline Chair/director & $21(6 \%)$ & $18(23 \%)$ \\
\hline Provost & $4(1 \%)$ & $2(3 \%)$ \\
\hline Associate / vice dean & $3(1 \%)$ & $3(4 \%)$ \\
\hline Other & $20(6 \%)$ & $1(1 \%)$ \\
\hline \multicolumn{3}{|l|}{ Institution (350 members) } \\
\hline Public & $238(68 \%)$ & $52(68 \%)$ \\
\hline Private & $112(32 \%)$ & $23(30 \%)$ \\
\hline Public/private & & $1(1 \%)$ \\
\hline \multicolumn{3}{|l|}{ Gender ( 350 self-reported) } \\
\hline Men & $297(85 \%)$ & $57(75 \%)$ \\
\hline Women & $51(15 \%)$ & $18(24 \%)$ \\
\hline Other/prefer not to answer & $2(<1 \%)$ & 1 \\
\hline \multicolumn{3}{|c|}{$\begin{array}{l}\text { Race/ethnicity (195 self-reported to } \\
\text { ASEE; } 74 \text { reported in national survey) }\end{array}$} \\
\hline White & $150(77 \%)$ & $63(83 \%)$ \\
\hline Asian/Pacific Islander & $21(11 \%)$ & $7(9 \%)$ \\
\hline African American/Black & $15(8 \%)$ & $1(1 \%)$ \\
\hline Native American/Alaskan Native & 0 & 0 \\
\hline Hispanic & $9(5 \%)$ & $3(4 \%)$ \\
\hline
\end{tabular}

The sample was generally representative of the ASEE-EDC membership of white male academics in schools of engineering. The majority of respondents held the role of dean of schools of engineering or computing sciences, representing $17 \%$ of all deans in the EDC membership. Comparable to member organizations in the ASEE, the respondents came from 52 public and 23 private institutions from across the United States. The majority (83\%) identified as White or non-Hispanic and the sample did not differ significantly from the population of EDC members in terms of race $\left(\chi^{2}=3.46, p=0.063\right.$ [df $=1, N=75]$ ). Although the composition of both the survey sample and the EDC membership is predominantly men, the $24 \%$ proportion of women survey respondents represents a significantly higher proportion than in the general EDC, whose membership is $85 \%$ men $\left(\chi^{2}=5.78, p=0.016[\mathrm{df}=1\right.$, $\mathrm{N}=75])$.

\subsection{Respondents' Assessment of the Importance of and Their Self-Confidence in Select Leadership Skills}

Table 2 shows results of the survey of leadership skills by frequency and median response, reflecting participants' assessments of the importance of each skill and of their self-confidence in performing the skill. 
Table 2. Engineering education leaders' ratings of the importance of and their confidence in leadership skills.

\begin{tabular}{|c|c|c|c|c|c|c|c|c|}
\hline \multirow[t]{3}{*}{ Leadership Skills } & \multicolumn{4}{|c|}{ How IMPORTANT Is This to You? } & \multicolumn{4}{|c|}{ How CONFIDENT Are You in Your Ability to Do This? } \\
\hline & \multicolumn{3}{|c|}{ Frequency of Selecting Option (\%) } & \multirow[t]{2}{*}{ Median Rating } & \multicolumn{3}{|c|}{ Frequency of Selecting Option (\%) } & \multirow[t]{2}{*}{ Median Rating } \\
\hline & $\begin{array}{c}\text { Not at } \\
\text { all/minimally }(1,2)\end{array}$ & Moderately $(3,4)$ & Very $(5,6)$ & & $\begin{array}{c}\text { Not at } \\
\text { all/minimally }(1,2)\end{array}$ & Moderately $(3,4)$ & Very $(5,6)$ & \\
\hline $\begin{array}{l}\text { Interpret budgets/financial statements to analyze } \\
\text { allocation of resources }\end{array}$ & $1(1.2)$ & $9(10.6)$ & $75(88.2)$ & 6 & $3(3.6)$ & $18(21.1)$ & $64(75.3)$ & 5 \\
\hline $\begin{array}{l}\text { Leverage existing and new resources for } \\
\text { organizational improvement }\end{array}$ & $0(0)$ & $1(1.2)$ & $84(98.8)$ & 6 & $2(2.4)$ & $22(25.9)$ & $61(71.8)$ & 5 \\
\hline $\begin{array}{l}\text { Engage senior institutional leaders and staff to } \\
\text { execute organizational projects }\end{array}$ & $0(0)$ & $7(8.3)$ & $78(91.7)$ & 6 & $1(1.2)$ & $25(29.4)$ & $59(69.4)$ & 5 \\
\hline $\begin{array}{l}\text { Develop written and verbal messages to meet the } \\
\text { needs of different audiences }\end{array}$ & $0(0)$ & $6(7.1)$ & $79(92.9)$ & 6 & $1(1.2)$ & $21(24.7)$ & $63(74.1)$ & 5 \\
\hline $\begin{array}{l}\text { Set priorities and manage time well to } \\
\text { meet deadlines }\end{array}$ & $0(0)$ & $4(4.7)$ & $81(95.3)$ & 6 & $5(5.9)$ & $25(29.4)$ & $55(64.7)$ & 5 \\
\hline $\begin{array}{l}\text { Practice habits that maintain physical and } \\
\text { emotional well-being }\end{array}$ & $0(0)$ & $7(8.2)$ & $78(91.7)$ & 6 & $11(12.9)$ & $36(42.4)$ & $38(44.7)$ & 4 \\
\hline $\begin{array}{l}\text { Partner with institutional administrative } \\
\text { departments to execute projects }\end{array}$ & $0(0)$ & $18(21.2)$ & $67(78.8)$ & 5 & $2(2.4)$ & $16(18.8)$ & $67(78.9)$ & 5 \\
\hline Manage stakeholder expectations & $1(1.2)$ & $16(18.9)$ & $68(80.0)$ & 5 & $3(3.6)$ & $26(30.6)$ & $56(65.9)$ & 5 \\
\hline $\begin{array}{l}\text { Support continuing leadership development } \\
\text { of faculty }\end{array}$ & $0(0)$ & $23(27.1)$ & $62(73.0)$ & 5 & $1(1.2)$ & $36(42.4)$ & $48(56.5)$ & 5 \\
\hline $\begin{array}{l}\text { Expand your professional relationships outside of } \\
\text { your specialty/ discipline/field of training }\end{array}$ & $1(1.2)$ & $20(23.5)$ & $64(75.3)$ & 5 & $3(3.5)$ & $30(35.3)$ & $52(61.2)$ & 5 \\
\hline $\begin{array}{l}\text { Develop professional goals that align with the } \\
\text { organizational goals a }\end{array}$ & $3(3.5)$ & $24(28.2)$ & $57(67.0)$ & 5 & $3(3.5)$ & $28(33.0)$ & $53(62.4)$ & 5 \\
\hline $\begin{array}{l}\text { Make career decisions based on clear personal } \\
\text { and professional goals }{ }^{\mathrm{b}}\end{array}$ & $4(4.7)$ & $15(17.6)$ & $64(75.3)$ & 5 & $4(4.7)$ & $35(41.2)$ & $44(51.8)$ & 5 \\
\hline $\begin{array}{l}\text { Adapt approaches to leadership challenges by } \\
\text { leveraging personal and professional strengths }\end{array}$ & $0(0)$ & $10(11.8)$ & $75(88.2)$ & 5 & $3(3.5)$ & $32(37.7)$ & $50(58.8)$ & 5 \\
\hline $\begin{array}{l}\text { Develop initiatives in a fashion that makes the } \\
\text { best use of individual team members' strengths }\end{array}$ & $0(0)$ & $7(8.2)$ & 78 (91.8) & 5 & $1(1.2)$ & $32(37.7)$ & $52(61.2)$ & 5 \\
\hline
\end{tabular}

Note: Eighty-five members (24\%) of the Engineering Deans Council of the American Society for Engineering Education responded to the 2014 Academic Leadership survey. Values represent the frequency with which respondents rated the importance of each skill and their confidence in performing the skill. The survey used a numeric rating scale of 1-6, from 1 (Not at all important/confident) to 6 (Very important/confident). For this analysis, ratings were combined, with 1 and 2 combined as Not at all or minimally important/confident, 3 and 4 combined as Moderately important/confident, and 5 and 6 combined as Very important/confident. Items are ordered in the table by descending median ratings of importance. ${ }^{\text {a }}$ Missing values $=1$ (1.2\%), ${ }^{\mathrm{b}}$ Missing values $=2(2.4 \%)$. 
Respondents to the Academic Leadership Survey tended to rate items at the high end of the six-point scale. They rated $85 \%$ of all items pertaining to importance as very or extremely important. The ratings for self-confidence in their skills were lower, with only $64 \%$ of items rated as very/extremely confident.

This sample of engineering leaders gave the highest ratings of importance (median $=6$ ) to the activities of interpreting budgets, leveraging resources, engaging others in project execution, developing audience-specific messages, managing time and priorities, and practicing habits of well-being. Regarding their own self-confidence, respondents rated all but one item relatively high (median $=5$ ), and they rated that item (practices for maintaining well-being) at 4 . This lower rating of 4 for self-confidence stands in contrast to respondents' rating of 6 for this item in importance. Although $92 \%$ of this sample rated the item on maintaining well-being as a 5 or 6 in importance, only $45 \%$ rated their self-confidence in performing the item as a 5 or 6 .

\subsection{Developing Academic Leaders-Mentoring and Sponsorship Leadership Practices}

Survey respondents had an opportunity to report the mentoring and sponsorship practices they had undertaken on behalf of up to three emerging leaders. Of the 85 leaders responding to the survey, one third (27) indicated that they had never mentored or sponsored a faculty member for a leadership position-a finding of concern for academic leadership development. The other 49 (including 40 men and nine women) described their mentoring practices for 94 different protégés; 27 of these (20 men, seven women) also described support for a second protégé; and 14 of the 27 (10 men, four women) also described a third protégé. Table 3 shows the responses associated with the 94 academic leader-protégé reports, displayed by mentoring and sponsorship practices in order of this sample's most to least frequently utilized.

Of the eight mentorship practices described, none were utilized universally. The respondents reported using two practices extensively (used frequently for $79 \%$ to $88 \%$ of the protégés)—providing candid feedback and discussion of political strategies. Four practices-supporting attendance at external development programs, seeking feedback about protégés' performance, holding regular mentoring meetings, and advising on executive presence-were used frequently, with $52 \%$ to $66 \%$ of the protégés. Guidance in strategic career development and shadowing opportunities were offered "frequently" less than half the time.

Five of the 12 sponsorship practices-public acknowledgment of achievements, public support for difficult or unpopular decisions, appointment to high-level committees, appointment to administrative roles, and nomination for advancement-were utilized frequently for more than $75 \%$ of the protégés. Four additional practices were used with less consistency: Sending protégés in the leader's place to important meetings, having protégés give presentations to executive groups, providing introductions to extend protégés' professional networks, and paving the way to leadership by preparing others to support or backfill the new leaders' current roles. Three practices were reported as being utilized infrequently (for less than $40 \%$ of protégés)—engaging consultants, providing support for executive coaching, and privately negotiating to advance the protégé. 
Table 3. Mentoring and sponsorship behaviors used by engineering education leaders to support emerging leaders.

\begin{tabular}{|c|c|c|c|c|c|c|c|c|c|}
\hline \multicolumn{5}{|c|}{ Mentorship } & \multicolumn{5}{|c|}{ Sponsorship } \\
\hline \multirow[t]{2}{*}{ Behavior/Action (Median Response) } & \multicolumn{4}{|c|}{ Percent Selecting Response } & \multirow[t]{2}{*}{ Behavior/Action (Median Response) } & \multicolumn{4}{|c|}{ Percent Selecting Response } \\
\hline & $\begin{array}{l}\text { Always/Most } \\
\text { of the Time }\end{array}$ & Occasionally & Never & Not Applicable & & $\begin{array}{l}\text { Always/Most } \\
\text { of the Time }\end{array}$ & Occasionally & Never & Not Applicable \\
\hline Provide her/him with candid feedback (2) & 88.3 & 11.7 & 0 & 0 & $\begin{array}{l}\text { Publicly acknowledge her/his talents and } \\
\text { achievements (3) }\end{array}$ & 88.3 & 11.7 & 0 & 0 \\
\hline $\begin{array}{l}\text { Discuss strategies for managing interpersonal } \\
\text { politics (2) }\end{array}$ & 78.7 & 19.1 & 2.1 & 0 & $\begin{array}{l}\text { Publicly support when he/she makes a } \\
\text { difficult or unpopular decision ( } 3 \text { ) }\end{array}$ & 81.9 & 9.6 & 1.1 & 7.4 \\
\hline $\begin{array}{l}\text { Support attendance at leadership programs } \\
\text { outside of the home institution (2) }\end{array}$ & 66.0 & 18.1 & 10.6 & 5.3 & $\begin{array}{l}\text { Appoint to high-level committees/task } \\
\text { forces (2) }\end{array}$ & 84.0 & 12.8 & 0 & 3.2 \\
\hline $\begin{array}{l}\text { Seek feedback as to how she/he is doing in } \\
\text { the new leadership position (2) }\end{array}$ & 58.5 & 27.7 & 9.6 & 4.3 & $\begin{array}{l}\text { Directly nominate her/him for } \\
\text { advancement positions (2) }\end{array}$ & 75.4 & 17.0 & 1.1 & 6.4 \\
\hline $\begin{array}{l}\text { Set aside meetings on your calendar for } \\
\text { regular mentoring (2) }\end{array}$ & 55.3 & 37.2 & 7.4 & 0 & $\begin{array}{l}\text { Assign her/him to an administrative role } \\
\text { that tests new management skills (2) }\end{array}$ & 75.3 & 20.0 & 0 & 4.2 \\
\hline $\begin{array}{l}\text { Advise her/him on executive presence and } \\
\text { communications (2) }\end{array}$ & 52.1 & 34.0 & 10.6 & 4.3 & $\begin{array}{l}\text { Introduce her/him to individuals or } \\
\text { groups to extend her/his professional } \\
\text { networks (2) }\end{array}$ & 65.9 & 27.7 & 3.2 & 3.2 \\
\hline $\begin{array}{l}\text { Guide her/him in development of an } \\
\text { intentional and strategic plan for } \\
\text { advancement to leadership (1.5) }\end{array}$ & 48.9 & 37.2 & 11.7 & 2.1 & $\begin{array}{l}\text { Send in your place to important meetings, } \\
\text { speaking appearances, and events (2) }\end{array}$ & 58.6 & 27.7 & 4.3 & 9.6 \\
\hline \multirow[t]{5}{*}{ Provide opportunity to shadow you (1) } & 31.9 & 24.5 & 30.9 & 12.8 & $\begin{array}{l}\text { Give an opportunity to present to } \\
\text { executive groups (e.g., board meetings) (2) }\end{array}$ & 58.5 & 31.9 & 4.3 & 5.3 \\
\hline & & & & & $\begin{array}{l}\text { Pave the entry to leadership by preparing } \\
\text { other faculty for the new leader's role (2) }\end{array}$ & 51.1 & 27.7 & 12.8 & 8.5 \\
\hline & & & & & $\begin{array}{l}\text { Provide formal support for leadership } \\
\text { coaching (1) }\end{array}$ & 38.3 & 28.7 & 26.6 & 6.4 \\
\hline & & & & & $\begin{array}{l}\text { Privately negotiate with colleagues to } \\
\text { advance protégé (1) }\end{array}$ & 27.2 & 34 & 27.7 & 11.7 \\
\hline & & & & & $\begin{array}{l}\text { Engage a team of advisors and } \\
\text { consultants to support (1) }\end{array}$ & 13.8 & 41.5 & 35.1 & 9.6 \\
\hline
\end{tabular}

Note: Eighty-five members (24\%) of the Engineering Deans Council of the American Society for Engineering Education responded to the 2014 Academic Leadership Survey. Forty-nine respondents described 94 different experiences with supporting faculty for leadership roles (49 described one, 27 described two, and 14 described three). Actions were scaled as Always, Most of the time, Occasionally, Never, or Not applicable. Ratings were assigned numerical values (Always =3, Most of the time $=2$, Occasionally $=1$, and Never or N/A = 0); they were reported as percent of respondents reporting frequency of use. Responses of Always/most of the time are combined as high-frequency responses. 


\section{Discussion}

The results of this national survey of academic engineering leaders conducted with the ASEE-EDC membership highlight the importance of a set of leadership skills and practices, including mentoring and sponsorship, that apply to academic leaders and that are used in leadership development programs, such as ELAM at Drexel ${ }^{\circledR}$ (Executive Leadership in Academic Medicine, Philadelphia, U.S.A) and ELATE at Drexel ${ }^{\circledR}$ (Executive Leadership in Academic Technology and Engineering, Philadelphia) (Magrane and Morahan 2016).

\subsection{Leadership Skills: Importance and Confidence}

The list of skills reflects academic leadership skills reported by leadership practitioners and by scholars from a variety of disciplines (Rich et al. 2008; Magrane and Morahan 2016; Wilkes et al. 2015; Gmelch et al. 2017). Our respondents gave high ratings for both importance and self-confidence to skills of transactional management: Interpreting budgets and managing resources, communication skills in messaging, and engaging other administrators in project development. This finding is not surprising given that these are skills that transition well from the management of academic grants and research projects. According to a recent study of engineering leaders, these skills define technical mastery and collaborative optimization (Rottmann et al. 2015). The lower ratings for self-confidence regarding these skills are similar to ratings reported in a large national survey of department chairs (Gmelch et al. 2017), which was a follow-up study to Gmelch's survey of chairs more than two decades ago (Gmelch and Miskin 1993).

\subsection{Mentoring and Sponsorship: Practices}

Results of large-scale surveys, interviews with senior executives of multinational companies, and interviews of high-potential professionals with MBAs participating in their companies' mentoring programs have shown that a critical element in advancement was the mentor's use of "organizational clout" to advocate for the advancement of his or her protégé (Hewlett et al. 2010; Ibarra et al. 2010). Although the importance of mentoring in the academy has been researched and discussed for years, one third of the executive leaders in the current sample reported they had not mentored or sponsored a protégé for a leadership role. This finding is consistent with national studies of corporate executive advancement in which most women $(83 \%)$ and men $(76 \%)$ reported having a mentor, but fewer reported having a sponsor (13\% of women and 19\% of men) (Carter and Silva 2010). A follow-up study credited the gender difference in sponsorship with a $15 \%$ promotion advantage for men (Ibarra et al. 2010). Similarly, a survey study of recipients of National Institutes of Health grants showed a relationship between sponsorship activities and academic research success; $73 \%$ of men and $59 \%$ of women who reported having received sponsorship advanced to major principal investigator or administrative research roles, compared with $58 \%$ of men and $45 \%$ of women who did not report sponsorship (Patton et al. 2017).

Respondents to the current survey reported using a variety of methods in sponsoring emerging leaders, particularly public sponsorship practices, such as acknowledgment of protégés' achievements and support for their difficult decisions. Three "behind the scenes" sponsorship activities that are well described in research on corporate career development were reported infrequently by academic leaders in the current sample-negotiations to advance protégés, executive coaching, and enlistment of a team of advisors. This range of practices is consistent with findings from interviews with STEM senior academic leaders, and particularly with their roles as institutional strategists (Magrane et al. 2018). Each of these practices takes advantage of a leader's positional power and draws on his or her strategic use of resources to enhance the potential success of a promising protégé; these actions may be the most influential types of sponsorship (Ibarra et al. 2010; Hewlett et al. 2011).

Leading-edge corporations are using professional development approaches that support one-on-one sponsorship relationships for both women and men (Hewlett et al. 2011). Although little is known about 
such practices within higher education, there is no reason to believe that such programs would not benefit leaders in higher education as well. Such approaches are consistent with recommendations to reduce barriers to advancement in higher education (Travis 2013; DeZure et al. 2014; Helitzer et al. 2016) and merit additional attention in research on leadership development for universities.

Figure 1 provides a self-reflection instrument regarding mentoring and sponsorship practices that can be used for individual reflection and group discussion. This may be useful for both leaders who are developing protégés and for aspiring leaders.

Consider a current protégé with interests and talents in academic leadership. Reflect on how often you engage in the following practices.

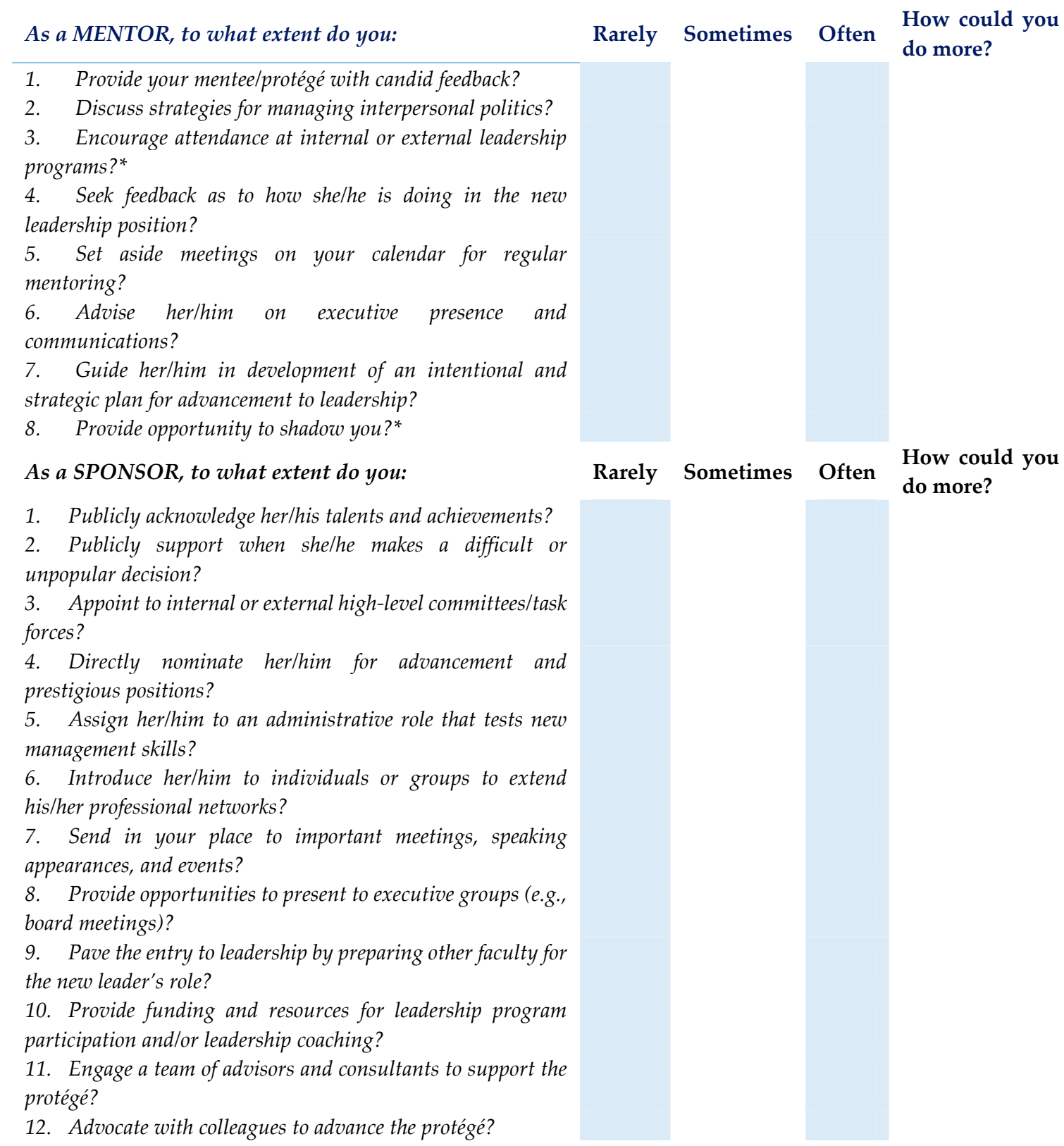

Figure 1. Leadership Mentoring and Sponsoring Self-Assessment. * Note that some "mentoring" practices can be "sponsorship" if they are public and funded. 


\subsection{Limitations}

As with survey studies in general, responses to the national survey represent leaders' self-assessments, which were not corroborated by external observations or judgments, or by direct reports from supervisors or protégés. Also, terms were not defined in the survey items, meaning that respondents' interpretations may have influenced their answers. Respondents may have rated one item in particular- "negotiations to advance the protégé"-lower if they interpreted "negotiation" to refer to trading or coercion, rather than advocacy. For this reason, the word, "negotiation", is replaced with the phrase, "advocacy for", in the Leadership Mentoring and Sponsorship Practices Self-Assessment (Figure 1). Also, some of the variations in how frequently leaders employ certain mentoring and sponsorship actions may be influenced by their proximity (geographically or organizationally) to the protégé. For example, if a protégé works for an organization outside of the mentor's influence, the mentor would not be able to make appointments or to employ coaches and advisors to help the protégé. Neither would it be easy to provide shadowing opportunities or to send the protégé as proxy to important meetings when the protégé is not part of the same organization as the sponsor. It is worth noting that the definitions of mentoring and sponsorship may be contextual for these partnerships; some "mentoring" practices, such as shadowing programs and support for professional development, contribute to "sponsorship" when the support is visible to the organization and its leadership.

The response rate to the survey was relatively low, and respondents were likely drawn from a sample population that is more engaged in developing faculty leaders, particularly diverse faculty leaders, than the general population of academic engineering leaders. While this limitation precludes statistical evaluation of the survey instrument, the findings of significant gaps in sponsorship behaviors give credence to actions that might strengthen professional development in talent management for all academic engineering leaders. Thus, the results are presented as descriptive and instructional for advancing faculty as leaders. The survey should not be construed as having undergone external validation as a tool for evaluation. Rather, it serves as a preliminary assessment of a sample population of academic leaders. Items from the Academic Leadership Survey used here may be adapted or incorporated into future instruments for program evaluation and leadership coaching.

\section{Conclusions}

Academic leadership is challenged with developing and expanding the leadership and management skills that leaders learn as scholars and extending the relational skills they need to be effective organizational strategists. The findings of this study situate a portfolio of leadership development practices that are being used to expand and diversify the corporate workforce within the context of academic leadership. While the current findings are based upon a population of leaders in academic engineering, the results are similar to those found with leadership in STEM and the humanities across universities and colleges.

The academic engineering leaders who responded to this national survey report using a variety of leadership skills, including those of sponsorship. This is encouraging. However, it is concerning that one-third did not identify a junior colleague for whom they had provided mentorship and/or sponsorship to become a leader. This level of prevalence of behaviors to foster leadership succession is less than ideal and risks inhibiting efforts to encourage faculty to explore academic administrative leadership roles, especially for women and faculty of color who have less access to the network of traditional leadership mentoring opportunities.

These findings offer a rich menu for professional development of already talented and motivated academic leaders. Training and support programs require attention to the mentoring and sponsorship leadership practices outlined in the Leadership Mentoring and Sponsorship Practices Self-Assessment (Figure 1) as well as management and leadership skills, such as those described in the Academic Leadership Survey (Table 2). Their potential uses to increase awareness of a portfolio of behaviors to advance leadership opportunities include as (1) a checklist for faculty to review as a career development tool or in identifying and working with mentors/ sponsors; (2) a guide for mentors/sponsors to use for 
reflection on their mentoring and sponsoring behaviors; and (3) a framework for mentor-protégé conversations around experiences and skill development that expand leadership abilities. As a reference for the design of educational programs, it can be useful in developing lessons for career coaching or professional development workshops as well as for evaluating leadership program outcomes. In addition, selected items might be incorporated into performance evaluation or used when screening applicants for leadership roles that incorporate support for the career development of diverse faculty.

Awareness of need, as well as understanding the possible practices that are being used effectively by sitting leaders, are requisite for culture change that advances talented leaders and organizational innovation. This will require that faculty and leaders-protégés and sponsors—share responsibility for leadership development and incorporate mentoring and sponsorship into core leadership practices. Universities that hold themselves accountable for professional development for their leaders are likely to discover the lessons of corporate America - that the intentional development of diverse leaders from department chair through presidential staff carries advantages in leading in innovation and addressing societal challenges. Such an investment seems prudent for all of higher education.

Author Contributions: D.M. is principal investigator of the Cornerstones of Leadership Program Evaluation project; S.A.D. conducted the statistical analyses. All authors participated in the design of the survey, analysis of results, and composition of this manuscript. Conceptualization, D.M., P.S.M., S.D. and S.A.; Formal analysis, S.A.D.; Funding acquisition, D.M.; Investigation, D.M., P.S.M., S.A. and S.A.D.; Methodology, S.A. and S.A.D.; Project administration, D.M.; Validation, P.S.M. and S.A.; Writing-Original Draft, D.M., P.S.M. and S.A.D.; Writing-Review \& Editing, S.A.

Funding: This work was supported in part by a grant from the Alfred P. Sloan Foundation (Grant \#2012-12-03).

Acknowledgments: The authors would like to acknowledge Norman Fortenberry and his staff at the American Society for Engineering Education for assistance with dissemination of the survey to members; the contributions of Brenda Seals, PhD, and Nily Dan, PhD, in developing the Academic Leadership Survey; and Wenting Luo, MPH, and Ekta Panjrolia, MS, for organization of survey components and initial results. We appreciate the corrections and feedback of Diana Winters for her professional editing of this manuscript.

Conflicts of Interest: Two authors (Diane Magrane and Susan Ambrose) were involved in development of the ELATE @ Drexel program; the other two (Page S. Morahan and Sharon A. Dannels) had no role in the ELATE program.

\section{References}

Betts, Kristen, David Urias, and Keith Betts. 2009. Higher Education and Shifting US Demographics: Need for Visible Administrative Career Paths, Professional Development, Succession Planning \& Commitment to Diversity. Academic Leadership: The Online Journal 7: 6. Available online: http://scholars.fhsu.edu/alj/vol7/ iss2/ 6 (accessed on 19 June 2018).

Blumenstyk, Goldie. 2005. Outside Chance for Insiders. A Chronicle Survey: What Presidents Think. The Chronicle of Higher Education 52: A28-A29. Available online: https:/ / www.chronicle.com/article/Outside-Chancefor-Insiders/23524 (accessed on 19 June 2018).

Carter, Nancy M., and Christine Silva. 2010. Mentoring: Necessary but Insufficient for Advancement. Catalyst.org. Available online: http://www.catalyst.org/system/files/Mentoring_Necessary_But_Insufficient_for_ Advancement_Final_120610.pdf (accessed on 19 June 2018).

Clunies, Jonathon. 2004. Benchmarking Succession Planning and Executive Development in Higher Education. Academic Leadership Journal: The Online Journal 2: 3. Available online: http://scholarsfhsu.edu/alj/vol2iss4/3 (accessed on 31 March 2018).

Cohen, Ronald J., and Mark Swerdlik. 2005. Psychological Testing and Assessment, 7th ed. Boston: McGraw-Hill Higher Education, ISBN 10:0073129097.

DeZure, Deborah, Allyn Shaw, and Julie Rojewski. 2014. Cultivating the next generation of academic leaders: Implications for administrators and faculty. Change: The Magazine of Higher Learning 46: 6-12. [CrossRef]

Gigliotti, Ralph A., and Brent D. Ruben. 2017. Preparing higher education leaders: A conceptual, strategic, and operational approach. Journal of Leadership Education 16: 96-114. [CrossRef] 
Gmelch, Walter H. 2004. The department chair's balancing acts. New Directions for Higher Education 126: 69-84. [CrossRef]

Gmelch, Walter H. 2000. Leadership succession: How new deans take charge and learn the job. Journal of Leadership and Organizational Studies 7: 68-87. [CrossRef]

Gmelch, Walter H., Drew Roberts, Kelly Ward, and Sally Hirsch. 2017. A retrospective view of department chairs: Lessons learned. The Department Chair 28: 1-4. [CrossRef]

Gmelch, Walter H., and Val D. Miskin. 1993. Leadership Skills for Department Chairs. Bolton: Anker, pp. 88-89. ISBN 0962704261.

González, Cristina. 2010. Leadership, Diversity and Succession Planning in Academia. Berkeley: Center for Studies in Higher Education, University of California, Available online: http:/ / escholarship.org/uc/item/594483fq (accessed on 19 June 2018).

Helitzer, Deborah L., Sharon L. Newbill, Gina Cardinali, Page S. Morahan, Shine Chang, and Diane Magrane. 2016. Narratives of participants in national career development programs for women in academic medicine: Identifying the opportunities for strategic investment. Journal of Women's Health 25: 360-70. [CrossRef] [PubMed]

Hewlett, Sylvia A., Kerrie Peraino, Laura Sherbin, and Karen Sumberg. 2010. The Sponsor Effect: Breaking through the Last Glass Ceiling. Harvard Business Review Research Report. Available online: http:/ /30percentclub. org/wp-content/uploads/2014/08/The-Sponsor-Effect.pdf (accessed on 9 July 2018).

Hewlett, Sylvia A., Melinda Marshall, and Laura Sherbin. 2011. The Relationship You Need to Get Right: How to Be an Effective Sponsor-And a Good Protégé-Throughout Your Career. Harvard Business Review. Available online: https:/ /hbr.org/2011/10/the-relationship-you-need-to-get-right (accessed on 19 June 2018).

Ibarra, Herminia, Nancy M. Carter, and Christine Silva. 2010. Why Men Still Get more Promotions than Women. Harvard Business Review 88: 80-85. Available online: https://hbr.org/2010/09/why-men-still-get-morepromotions-than-women (accessed on 19 June 2018).

Kaufman, Barbara. 2006. The role of executive coaching in performance management. Handbook of Business Strategy 7: 287-91. [CrossRef]

King, Gary, and Maya Sen. 2013. The troubled future of colleges and universities. Political Science and Politics 46: 83-89. [CrossRef]

Korn Ferry Institute. 2015. Succession Matters: Effective Succession Planning. Available online: https:/ / www.kornferry.com/institute/succession-matters-effective-succession-management-planning? popular (accessed on 18 June 2018).

Magrane, Diane, and Page S. Morahan. 2016. Fortifying the pipeline to leadership: The International Center for Executive Leadership in Academics at Drexel. In FORWARD to Professorship in STEM: Inclusive Faculty Development Strategies That Work. Edited by Rachelle Heller, Catherine Mavriplis and Paul Sabila. London, San Diego, Waltham and Oxford: Academic Press, pp. 319-36. ISBN 9780128008553.

Magrane, Diane M., Page S. Morahan, Susan Ambrose, and Sharon A. Dannels. 2018. Institutional matchmakers, sponsors, and strategists: Roles of academic STEM executives in developing the next generation of leaders. Open Journal of Leadership 7: 168-86. [CrossRef]

Morahan, Page S., Sharon Newbill, Diane Magrane, Sally Shumaker, Doug Easterling, Aleya Lyn, and Shine Chang. 2016. Managing Mission Tensions in Academic Health Centers. The Pharos 79: 8-13. Available online: http:/ / alphaomegaalpha.org/pharos/PDFs/2016-4-Morahan.pdf (accessed on 19 June 2018).

Patton, Elizabeth W., Kent A. Griffith, Rochelle D. Jones, Abigail Stewart, Peter A. Ubel, and Reshma Jagsi. 2017. Differences in mentor-mentee sponsorship in male vs female recipients of National Institutes of Health grants. JAMA Internal Medicine 177: 580-82. [CrossRef] [PubMed]

Rich, Eugene C., Diane Magrane, and Darrell G. Kirch. 2008. Qualities of the medical school dean: Insights from the literature. Academic Medicine 83: 483-87. [CrossRef] [PubMed]

Rizvi, Saad, Katelyn Donnelly, and Michael Barber. 2013. An Avalanche Is Coming. Higher Education and the Revolution Ahead. London: Institute for Public Policy Research, Available online: http://www. ippr.org/publications/an-avalanche-is-coming-higher-education-and-the-revolution-ahead (accessed on 19 June 2018). 
Rottmann, Cindy, Robin Sacks, and Douglas Reeve. 2015. Engineering leadership: Grounding leadership theory in engineers' professional identities. Leadership 11: 351-73. [CrossRef]

Rowley, Daniel J., and Herbert Sherman. 2003. The special challenges of academic 12eadership. Management Decision 41: 1058-63. [CrossRef]

Travis, Elizabeth L. 2013. Sponsorship: A Talent Management Imperative for Science. Association for Women in Science. Available online: https:/ / c.ymcdn.com/sites/awis.site-ym.com/resource/resmgr/Magazine_ Article/Sponsorship.pdf (accessed on 19 June 2018).

Wilkes, Lesley M., Wendy Cross, Debra Jackson, and John Daly. 2015. A repertoire of leadership attributes: An international study of deans of nursing. Journal of Nursing Management 23: 279-86. [CrossRef] [PubMed]

C 2018 by the authors. Licensee MDPI, Basel, Switzerland. This article is an open access article distributed under the terms and conditions of the Creative Commons Attribution (CC BY) license (http://creativecommons.org/licenses/by/4.0/). 